University of Nebraska - Lincoln

DigitalCommons@University of Nebraska - Lincoln

$9-1-2006$

\title{
"Gorilla Trails in Paradise": Carl Akeley, Mary Bradley, and the American Search for the Missing Link
}

Jeannette Eileen Jones

University of Nebraska - Lincoln, jjones11@unl.edu

Follow this and additional works at: https://digitalcommons.unl.edu/historyfacpub

Part of the History Commons

Jones, Jeannette Eileen, "'Gorilla Trails in Paradise": Carl Akeley, Mary Bradley, and the American Search for the Missing Link" (2006). Faculty Publications, Department of History. 28.

https://digitalcommons.unl.edu/historyfacpub/28

This Article is brought to you for free and open access by the History, Department of at DigitalCommons@University of Nebraska - Lincoln. It has been accepted for inclusion in Faculty Publications, Department of History by an authorized administrator of DigitalCommons@University of Nebraska - Lincoln. 


\title{
"Gorilla Trails in Paradise": Carl Akeley, Mary Bradley, and the American Search for the Missing Link
}

\author{
Jeannette Eileen Jones
}

University of Nebraska-Lincoln

I n 1881, Ward's Natural Science Bulletin published the anonymously authored poem "The Missing Link." Referencing decades-long debates over the relationship of man to ape, and the spiritual, intellectual, and moral capacities of apes, chimpanzees, and orangutans (Desmond 45, 141, 289), the poem recounts the following tale of a simian king ordered by his council to find a bride. When pressed by his "lords of state" to "mate," as the time arose for him to perform his royal duties, the simian regent replied with indignation that he would not make a "mesalliance" with a chimpanzee. Despite assurances that the female of the lesser simian species would suffice as royal consort, the gorilla king declared that he would wait for someone worthy of his royal bloodline. Suddenly, from his treetop viewpoint, the sight of "a vision of beauty" never seen before-" "[a] maiden young and fair, [a]s the charcoal's ebon tint"- - surprised him. Her teeth were white as cowry shells, "[h]er locks of a crispy curl," and "[h]er feet of a mammoth size." The gorilla king felt so moved by this "bewitching dream" that he declared: "Now by my kingly troth, This maid shall be, I think, My royal bride, and supply beside Mr. Darwin's missing link." The African woman, "thoughtless" and "[s]uspicionless of guile" strayed beneath the trees where the simian court convened. When the "monarch spake his love" to her, "the lady smiled on him," at which point the gorilla king stuck "his great prehensile toes" in her hair and carried her off into his arboreal kingdom. "Thus was the monarch wed, [a]nd thus the race began, [w] hence, thro' various links, somewhat strange methinks, [c]ame the "Descent of Man!" (Ward's Natural Science Bulletin 8).

The Bulletin, the official journal of Henry Ward's Natural Science Establishment in Rochester, New York, enjoyed a wide readership in America and a selective reading audience in Europe. Ward's, an emporium, cabinet of curios, and taxidermy studio, boasted a reputation as one of the premier American (and Western) purveyors of natural history specimens (Kohlstedt, 647-48). In another poem "To the Gorilla in The Rochester University," which appeared in the Bulletin in 1882, the narrator questions the existence and purpose of the gorilla. At one point in the imaginary conversation with the stuffed animal on display, the author asks: "Could you not serve upon a rice plantation- $[\mathrm{r}]$ aise sugar-cane, and cotton, for the masses, [a]nd carry burdens, as do mules and

Jeannette Eileen Jones is an assistant professor of history and ethnic studies at the University of Nebraska-Lincoln. She conducts research in the areas of American cultural history and the history of science, with emphasis on race and representation. 
asses?" ("To the Gorilla" 9). Both poems reflected popular and scientific discourses concerning the relationship between man and the animal kingdom in light of the publication of "Mr. Darwin's" The Origin of Species (1859) and The Descent of Man (1871), and allude to the importance of the gorilla in those discussions. More specifically, the poems' authors speculated that Africans and African Americans were the key to unlocking the transition from ape to man, as popular and scientific thought configured "Negroes" closest to the simian in form and intellect. In this complex exposition of race and gender, popular thought imagined the female African body as the producer of "the missing link" — a half-man, half-beast creature that would reveal the key to the descent of man. Analogies drawn between Africans, African Americans, apes, and gorillas in "missing link" narratives assumed that African women submitted to animal couplings due in part to their perceived hyper and bestial sexuality (Collins 99). This discussion of possible couplings between African woman and gorilla reflected a broader American captivation with the missing link.

"Gorilla Trails in Paradise" explores the American obsession with primates and evolution, as informed by notions of race and sexuality, as an important current in American cultural and intellectual history during the late nineteenth and early twentieth centuries. This preoccupation began with queries regarding the relationship between man and ape in light of evolutionary theories that predated the publication of Darwin's seminal treatises. However, Darwinian evolution brought the question of that relationship into mainstream discourse. No longer confined to the musings of learned white men, the ape-human puzzle informed American popular thought and popular culture by the late nineteenth century.

This article explores how a group of middleclass Americans took up the search for the missing link by conducting a safari in Africa, and how their quest transformed and influenced American ruminations on the ape-human relationship. In this examination, the article discloses the transatlantic connections involving this pursuit of gorillas in the misty mountains of the Belgian Congo, particularly as those international links reflected and reinforced the politics of empire. Specifically, the article recounts and analyzes the Akeley African Expedition to the Belgian Congo conducted in 1921 under the auspices of the American Museum of Natural History (AMNH) to create an unparalleled gorilla diorama (a museum exhibit of stuffed animals posed in a simulated habitat). It tracks how the safari morphed into (1) a mission to rehabilitate the image of the gorilla and (2) a campaign for the preservation of the gorilla. The article places special emphasis on the relationship between the Belgian government and American scientists in creating the world's first gorilla sanctuary. Lastly, "Gorilla Trails in Paradise" discusses how the images of the gorilla as painted in the travel narratives of naturalist Carl Akeley and writer (and safari participant) Mary Hastings Bradley emerged and indeed became imbedded in cinematic culture.

I argue that the AMNH gorilla expedition and Akeley's quest to know the gorilla directly engaged America's search for the missing link. For Akeley, this mission entailed discounting fantasies of hypersexual and vicious ape behavior, as well as salacious theories of human-ape mating, which both reified and contested particular concepts of race, gender, and sexuality as understood by Americans. In his revisioning of the gorilla, Akeley upheld the image of the masculine ape-the ape as male progenitor of humanity, patriarchal ruler of the jungle, and masculine protector of his family. Yet, Akeley shied away from sensational sexualized descriptions of the masculine gorilla in his travel narratives. He achieved this by anthropomorphizing the male gorilla as father to a nuclear family, thereby denying his existence as part of roving bands, whose mating rituals seemed to suggest something other than monogamy. In contrast, his travel companion Mary Bradley exploited the popular image of the hypersexual ape in her travel narrative. Recognizing the gorilla as masculine father (and sometimes uncle), Bradley literarily fantasized about copulating with the progenitor-pledging to offer no resistance should the ape carry her away into the treetops. Here she complicat- 
ed views of white female sexuality. By offering to switch places with the Western constructed African woman, Bradley antagonized acknowledged "truths" about race, gender, and sexuality.

This article engages Donna Haraway's seminal work "Teddy Bear Patriarchy: Taxidermy in the Garden of Eden, New York City, 1908-1936" in Primate Visions: Gender, Race, and Nature in the World of Modern Science (1989). Haraway's analysis of Akeley's quest to capture the gorilla as a performance of patriarchy, reminiscent of Victor Frankenstein's elusive pursuit of his monster, is only one reading of his fascination with the gorilla. Perhaps an alternative (and more appropriate) literary reading of that infamous gorilla safari would employ Sigmund Freud's family romance theory as discussed in Totem and Taboo (1913). More extensive research into Akeley's quest to both create a definitive gorilla diorama and the world's first gorilla sanctuary, as well as a reading of his narrative of the gorilla expedition against Bradley's reveal a more complex interplay between ideas of gender, race, and sexuality.

As Todorov reminds us in The Morals of Histo$r y$, travel narratives project a writer's "ethical and aesthetic" values (6), and it is helpful to adopt his discussion of travel narratives in Europe to those of Akeley and Bradley. Akeley's and Bradley's accounts of the gorilla expedition are politicized narratives in that they are situated in what Todorov calls "the intellectual, cultural, and political climate from which they arose" (11-12). More concretely, Akeley and Bradley's American preoccupation with the cultural politics of the early twentieth century-eugenics, lynching, race riots, immigration policy, sexuality, and racial identityinform their narratives of the gorilla. The reader sees "personal narration" and not "objective description" (Todorov 67); that is, glimpses into the minds of the travelers and virtually nothing about Africa and the gorilla. Approaching these safari narratives from the stance of "critical colonial studies" and regarding them as practices (as defined by Pierre Bourdieu), I include them in what Ann Stoler calls "the range of practices in which racisms were produced." Thus, as the narratives reveal differing ideals of the gorilla-father figure and lover-they reflect what Stoler calls "a palpable obsession" with "whiteness" (Carnal Knowledge 13) - in this case, the need to reaffirm constantly their whiteness against the "blackness" of the primate and the African.

This article also engages Haraway's contention that the simian primate existed in the borderlands between culture and nature. I argue that this view can be extended to perceptions of Africans, whom Western thought also constructed as between culture (civilization) and nature-if not as exemplars of man in his natural state. In reading the Akeley and Bradley narratives we see the lines blurred between gorilla and man, yet the contemporaneous reader remained clear that the closest proximity between the two could be located in the African (or black) body. Thus, their primate stories upheld, not contested, racist portrayals of "Negroes" as ape-like beings.

\section{Gorillas, Real and Mythical}

Although American fascination with gorillas predated the appearance of Darwin's treatise on human evolution, it was not until the late nineteenth century, after the Europeans colonized Africa, that unlocking those "various links" between man and ape seemed possible. The European empire building project in Africa escalated in the late 1870s, when the French expanded their control of parts of Western Africa beginning with Senegal. By the 1880s, French economic interests included establishing commercial outposts in North and Central Africa. Other European nations followed suit, so that on the eve of the Berlin Conference of 1884, Britain, Germany, Spain, Belgium, Portugal, and Italy already had established claims to protectorates, colonies, and spheres of influence on the continent. The conference merely reflected the reality of events that unfolded a priori in Africa-the subjugation of indigenous peoples and the consolidation of economic power around strategic natural resources (Iliffe 187-93).

The fact that the publication of the missing link poems coincided with the intensification of 
imperialism in Africa was not by chance. The history of the 1880 s reveals that conversations on race, sexuality, and imperialism reinforced each other. As Ann Stoler reminds us in Race and the Education of Desire, "the nineteenth century imperial world" linked discourses on sexuality and the construction of race (19). Indeed, Francis Galton serves as a perfect example of how European imperialism inextricably tied race to sexuality. His experiences as both gentleman traveler in South West Africa and scientist exploring Central Africa as a member of the Royal Geographical Society during the 1850 s and 1860 s, fueled his belief that the human race could be improved by "selective breeding"—a "science" he termed engenics in 1883 (Bulmer 11-28, 79). Proponents of eugenics saw it as foremost a mechanism for policing sexuality and controlling race. That is, theoretically in its application it would decide what women could bear children and by whom. Fears that imperialism facilitated miscegenation and the loss of white manhood-particularly in intercourse between white European soldiers and women not of their "race" (Stoler, Carnal Knowledge 43-46) or worse, white women and black male servants-supported the equating of Africans with apes. If African bodies held the retrogressive and atavistic simian gene, logically, no one would risk giving birth to a degenerate ape-man/woman child.

Despite the fears of racialized sexual anarchy resulting from imperialism, the opening of the "Dark Continent" through colonial conquest made prospects of observing gorillas in their natural habitat more realizable. Before the 1884 partition of Africa, only four European menAndrew Battel, le Comte de Buffon, Thomas Savage, and Paul Du Chaillu-claimed to have seen the infamous primate (or something resembling it). Du Chaillu designated himself the only white man to have killed a gorilla (Schiebinger 78, 239 fn. 79; Akeley, In Brightest Africa 238). Colonial "improvements" and the bringing of modern conveniences to the continent (East Africa in particular) in the late nineteenth and early twentieth centuries inspired safaris, both personal and institutional, into the "jungle" to find "man's nearest relative." The 1902 encounter of German colonial officer Captain Robert von Beringe (erroneously referred to in naturalist literature as Oscar Beringer) with a mountain gorilla in German East Africa on the Virunga Volcanoes inspired a new generation of Westerners to travel to Africa in pursuit of the elusive simian (Barns 278; Warren).

In 1921, upon learning that famed white hunter Alfred Collins desired to travel to Africa to collect gorillas for the AMNH, Carl Akeley, American naturalist and former employee of Ward's, wrote museum President Henry Fairfield Osborn and outlined his "definite plans for a gorilla expedition." "He explained that for many years he had been contemplating securing gorillas for an exhibit that would be "authoritative in every sense." Akeley sought to capture mountain gorillas "discovered" by von Beringe and vowed to use his prospective expedition through the volcanic mountains of the Belgian Congo to fill a gap in natural historical literature about the gorilla. However, Akeley diplomatically agreed to defer his trip should the museum chose to back Collins. ${ }^{2}$ When the museum decided to endorse Akeley's expedition, he traveled to Africa with friends Martha Miller (Bliven), Priscilla Hall, Herbert, Mary, and "Baby Alice" Bradley, ${ }^{3}$ emphasizing his purpose of correcting "inaccurate theories that [had] persisted about little-known African animals," particularly the gorilla.

Akeley argued that "the study of this ape [the gorilla] is perhaps more interesting and more important than the study of any other African beast that has been the center of so many fables and superstitions," because many Westerners recognized the gorilla "as man's closest relative." Akeley imputed much of the historical misinformation about gorillas to the "inaccessibility" of the gorilla's habitat, combined with the "myths of an imaginative and superstitious people." Akeley, like many of his contemporary Americans, viewed Africans as irrational peoples, and thus he expressed no surprise at hearing "natives" attribute fantastical behaviors to the gorilla. However, the susceptibility of naturalists in believing and promulgating these "native" tales aggravated Akeley. According 
to Akeley, "merely writers rather than observers" internalized the stories heard from Africans or read in outdated natural history literature. These narratives accompanied the male naturalist into the field, and cast a "spell" on him, so "[w] hen he observes an animal in the distance and is unable to distinguish clearly what it is doing, he naturally interprets its actions in the light of the tale he has read." "Eyewitness testimony," that which bestowed authority on travel narratives as nodes of knowledge, thus evolved into "natural history fiction." Akeley recognized that existing narratives antagonized the scientist's unending endeavor to separate truth from fiction ("Gorillas" 429).

Akeley identified the writings of Battel, Buffon, Savage, and Du Chaillu as several among many of the sources of the "prevalent conception" of gorillas. The Portuguese captured Battel, an Englishman, in Angola during the 1580s. ${ }^{4}$ Akeley credited Battel with establishing "the idea that the ferocious beast walked erect, slept in trees, and was the terror of the natives" ("Gorillas" 436). Battel called the gorilla in his narrative Pongo. According to him, pongees (plural form) resembled men, except for their legs, which had no calves. Unlike humans, they ate only vegetables and lacked the power of speech. Their intelligence supposedly never surpassed that of any other beast. According to Battel, gorillas traveled together and killed many Africans working in the woods; they also pummeled trespassing elephants with fists and logs. In 1747, Antoine Prévost (Akeley mistakenly attributes the description to Buffon) included an "exaggerated translation" of Battel's description of the pongo in his Histoire générales des Voyages. Buffon's writings concentrated on the gibbon. The term gorilla first appeared in the writings of Thomas Savage (Schiebinger 239, fn. 79, 78). In an 1847 article in the Boston Journal of Natural History, Savage recounted a hunter's fatal encounter with the gorilla. The animal's "enormous jaws" were "widely opened at each expiration" as he shrieked "kh-ah! kh-ah ... presenting an aspect of indescribable ferocity" as he approached "the enemy in great fury" (qtd. in Akeley, "Gorillas" 436). Akeley conjectured that Savage's portrayal of the "ferocious" and "offensive" gorilla "proba- bly inspired in part at least the mounting of more than one ugly museum specimen." Akeley pledged to make his gorilla diorama pleasing to the museum patron's eye ("Gorillas" 436, 429).

Akeley cast further blame for propagating sensational images of the gorilla on Du Chaillu's narrative Explorations and Adventures in Equatorial Africa. In his tale of the chase, Du Chaillu wrote: "[T]ruly he [the gorilla] reminded me of nothing but some hellish dream creature-a being of that hideous sort, half man, half beast, which we find pictured by old artists is some representations of the infernal regions" (qtd. in Akeley, In Brightest Africa 238). Interestingly, Akeley did not condemn Du Chaillu for the images he elicited, but rather the publishers of his adventures and the expectations of the public. Akeley argued that the "first erroneous reports of the gorilla" surfaced "when publishers ... feared to rely upon the unadorned truth to hold the public's interest." Akeley warned that the patrons who expected to see the gorilla invented by these authors and "motion picture producers" in his exhibit would be sorely disappointed ("Gorillas" 436, 431).

Writers and film producers stood among many Westerners who misrepresented gorillas in cultural texts. Akeley once commented on French sculptor Emmanuel Frémiet's bronze statue "Gorilla and Woman" which won a medal at the Salon in 1887. The artist later gave the statue the AMNH. Akeley wrote:

It shows a beautifully modeled animal in the act of bearing away on his right arm a lovely native woman, who by the way has more of the earmarks of a Parisian model than of an African savage. The gorilla, of course, is walking erect, on his legs; one hand clasps his captive, the other hand contains a great rock, which presumably he is about to throw at his pursuers. Although they have already succeeded in lodging a huge arrow in his heart, he apparently has an abundance of strength and energy to defy them and make away with his prize. ("Gorillas" 430-431) 
The African female womb was Frémiet's ape's ultimate prize, just as it was for the gorilla in "The Missing Link." Akeley castigated the "misleading" nature of Frémiet's bronze and eschewed the theory of hypersexual male primates. It is telling that Akeley restricted his concern to the misrepresentation of the gorilla. He focused on the pose of the gorilla and the attributes of primate behavior it denoted. Although he characterized the "abduction of native women by vicious old male gorillas" as legend, he did little to rehabilitate the image of the African woman, as he so painstakingly did for the gorilla. Indeed, he joked that an African woman could never be as beautiful or aesthetically pleasing as a white $\mathrm{Pa}$ risian woman ("Gorillas" 430). More importantly, Akeley's critique of Frémiet's statue reflected his conviction to "bring back stories of beautiful Africa" and not the dark Africa fixed in the public mind. ${ }^{5}$

Unfortunately for Akeley, his female companions did not aspire to such lofty aims. When told that they (Martha Miller and Mary Bradley) would be "the only women [read white women] in the world who had seen wild gorillas," Bradley jested: "We hope they'd appreciate the trouble we were taking and if a wild gorilla would only appear and perform that much advertised act of carrying women off we wouldn't offer any resistance" $(98,112)$. Miller and Bradley suggested disappearing with their simian lover. Much like the men's decision to play the "savage" hunting the defenseless gorilla, the women jokingly exulted in the chance to "go primitive" sexually-to share one lover (a quasi-polygamous union) and to engage in an act that only African women reportedly performed. Miller and Bradley's sally challenged popular cultural views of white women's purity and figuratively closed the distance between black and white women's sexuality. Metaphorically, by embracing an "atavistic sexuality" (Gilman 263), Miller and Bradley defied attempts to "police" white women's bodies and mythologize them as separate and distinct from those of "Other" women. Why could not the white woman supply "Mr. Darwin's Missing Link?" (Ward's Natural History Bulletin 8). Perhaps the "missing link" was the offspring of a white woman and a gorilla. Bradley and Miller's imagined transgression threatened to undermine Akeley's intent, as it engaged images of dangerous, oversexed primates. More importantly, if we read Akeley's text as an exposition of white masculinity, the women's sexual fantasies undermined the virility of the mythologized Great White Hunter-the very self identity Akeley wished to establish on safari and in his travel narrative.

\section{Gorilla Trails in Paradise}

Upon arrival at the White Friars' Mission in Usumbura, Akeley heard tales of a gorilla killed nearby. Apparently, the animal had ravaged a banana grove owned by the regional chief, who subsequently sent out "his men" to chase the unarmed animal. Unfortunately, one of his trusty subjects fell victim to the gorilla. Enraged, the chief ordered the men to kill the gorilla with their spears. In his recollection of this story, Akeley questioned the "veracity of this tale" of men armed with sticks chasing a gorilla, and discounted the ferocity of the animal offender. He also showed little concern for the life of the African man, as he remarked that the chief underestimated the harmlessness of the animal. More importantly, the tale signaled that the safari party was "getting into the real gorilla country" and this pleased Akeley tremendously. The knowledge that they were getting close to the animal, "quickened the blood," as this mission represented "that last word in African adventure" (In Brightest Africa 200-01).

At Gissenyi, the Akeley party met the wife of T. Alexander Barns, a hunter collecting gorillas for the British Museum. There, the men left the women as they "push[ed] on into gorilla country." Akeley left with 30 of the 170 porters to secure the "first" moving pictures of gorillas in their natural habitat. He was both "nervous and anxious" about the prospect of seeing a gorilla as he traversed the landscape that recalled for him past adventures on Mt. Kenya years earlier (Akeley, In Brightest Africa 201-03; Bradley 98). Monotonous treks across walking paths and game trails gave way to the mo- 
ment of splendor, when Akeley saw his first gorilla track. He remembered,

I'll never forget it. In that mud hole were the marks of four great knuckles where the gorilla had placed his hand on the ground. There is no other track like this on earth-there is no other hand in the world so large ... As I looked at that track I lost the faith on which I had brought my party to Africa. Instinctively I took my gun from the boy. I knew then the feeling Du Chaillu described in his quaint phrase, "My feelings were really excited to a painful degree." I had more thrill from the sight of this first track than from anything that happened later. (In Brightest Africa 203)

Akeley's companions, the Bradleys, similarly recollected their first sight of gorilla prints. On this occasion, Mary Bradley joined her husband in the hunt. Upon hearing their guide refer to the prints as "big, big," she called the news "stirring" and set out to follow the tracks. Bradley wrote: "We followed with a feeling of tremendous exhilaration. It was the actual mark of the great beast we had come so far to see; he was there somewhere ahead of us, hidden in a turning of the green thicket-any moment a parting of the leaves might show us his black, twitching face and sparkling eyes" (107).

Akeley's hunt of the gorilla was arduous. At first glance, his narrative of the gorilla killings seems straightforward. A great white hunter surrounded by "forty odd" hands and guides endured unseen dangers to secure specimens for a museum. However, it bears noting that Akeley began his narrative of the hunt by reviewing all the false notions people held about the gorilla, particularly its ferocity. He wrote, "[T] his reputation is so firmly established in the popular mind" that his and Herbert Bradley's decision to take women and a girl child in Central Africa "was looked upon as madness." To rid his mind of these popular myths, Akeley fashioned a mantra to recite before he set out to "hunt the 'ferocious' gorilla in the heart of Africa": "I believe that the gorilla is normally a perfectly amiable creature. I believe that if he attacks man it is because he is being attacked or thinks he is being attacked. I believe that he will fight in self-defense and probably in defense of his family" (In Brightest Africa 196-97). The male gorilla behaves like any human male would. Indeed, in evolutionary terms, the human male inherited the gorilla's masculine impulse to protect. Akeley did not comment on "real" gorilla behavior; rather, he projected human values on it, figuratively and literally, walking in the prints of the primate.

Akeley's audience did not understand or know necessarily of the emotive properties of gorillas. More importantly, Akeley offered no scientific evidence of the complex emotional lives of primates as evinced in his reliance on safari-like encounters with the animals to describe their behaviors. Akeley had yet to systematically observe the gorilla outside the hunt; that is, as anything other than prey. Thus, his description of gorilla behavior in his creed was a well-crafted fiction, a deliberate equating of gorilla with man to illicit sympathy and a sense of familiarity from his readers. Yet, it is not simply the stated creed or the detached descriptions of evisceration that unmask Akeley's revisioning of the image of the gorilla. Rather, the human-like characteristics that he imparted to the primates as he stalked them, killed them, and prepared their death masks disclosed his desire to solidify the humanness of the gorillas.

In "Adventures on Mt. Mikeno," Akeley humanized the gorillas he shot, particularly "the old black female" and her son. By referring to the female gorilla as an "old black female," Akeley may have been playing on images of the "mammy" that popular culture often troped in precisely those terms. Also, for the first time in his recollection of gorilla hunting, Akeley designated his guides " $\mathrm{Ne}$ groes" (an American term for blacks), instead of boys or Africans. Akeley employed a more precise language to avoid confusing the reader, suggesting a confluence of his earlier descriptions of Africans and gorillas. In this retelling Akeley also put on the mantle of "savage" and "aggressor" as he recalled shooting the female and her offspring. The latter ran away, only to be located thir- 
ty minutes later, running about until speared by a guide. As Akeley looked down upon the infant gorilla's dying face he saw "a heartbreaking expression of piteous pleading" and reasoned that had the infant been able, he would have "come to [his human] arms for comfort" (In Brightest Afri$c a, 215-24)$. Here the prey ceased to be an object of science, but rather a mother and a son brutally killed by savage men (Akeley and the guide). Akeley reaffirmed the remorse clearly shown here after he shot another female gorilla mistaken for an "immature male." However, he consoled himself by reverting to scientific jargon to avoid guilt. The knowledge that the female was a "splendid large specimen" absolved him of murder despite his observation that the mother gorilla left a baby "crying piteously" but unscathed (In Brightest Africa 215-24). In his description of his gorilla encounters, Akeley endowed the gorillas with features and emotions reminiscent of human family interactions to reinforce notions of human-gorilla similarity.

The making of the "death masks" for the gorillas also contributed to the humanization of the gorilla family. Dating back to antiquity, death masks were literally impressions taken of the deceased's faces, often in an attempt to secure the sensation of the last breath and stare upon a sticky and pliable substance. The death mask had mystical qualities, capturing for posterity the imprint of death upon one's countenance. Cultures designed this ritual for humans as part of the rite of passage of dying and transition. Akeley's decision to create death masks of the gorillas symbolized an initiation of them into the human family and into a cultural practice that had been reserved for man. However, the death masks may have served another purpose. They could have been used to recreate the dimensions of the gorillas' faces for comparative analysis with humans-although there is little evidence that this was Akeley's purpose. What is interesting is that Akeley never mentioned making death masks of other animals killed while on safari.

After completing the death masks, Akeley sojourned into the forests of Mt. Mikeno, where he secured four more gorilla specimens and shot some three hundred feet of motion pictures of lone gorillas and gorilla bands. Traveling up the slopes of Mt. Karisimbi, the safari came upon "a magic spot" where the group spotted "a male gorilla in his savage haunts" that "didn't know his part." The lone male did not afford Akeley and Herbert Bradley the opportunity to "defend the ladies heroically from threatened death," to perform feats of masculine prowess. Rather, as if to confirm Akeley's creed, the animal with "huge, uncouth, slouching shoulders" remained motionless as Bradley shot the animal in the neck. But when the gorilla proved to still be alive and ran off, Bradley shot him again, killing him (Bradley 114, 116; Akeley, In Brightest Africa 225, 229).

Akeley's recounting of Bradley's killing of the ape upheld the image of the gorilla as noble king of the jungle. Akeley commented that the animal had shown no sign of aggression; it just sought to escape and made no sound as the men gunned it down. He lamented, “it took all one's scientific ardour to keep from feeling like a murderer" (In Brightest Africa 229-30). Akeley's use of the term murder is important here, as only humans could be victims of murder, as understood by Americans. Great white hunters customarily did not refer to the killing of animals or faunal specimens while on safari as murder. Yet, Akeley viewed the act of slaying a gorilla as murder, even as he took solace in knowing that the gorilla had not been killed for sport, but rather to advance science.

Mary Bradley also remembered seeing the gorilla being shot and it subsequently "plunging down the slope." She stated that she would "never forget the humanness of that black, upturned face." The gorilla's face concealed no ferocity, as its "normal expression was of a curiously mild and patriarchal dignity." The animal only seemed vicious when its mouth was open. Decrying any sentimentality, Bradley wrote, "you could see in that face a gleam of patient and tragic surmise, as if the old fellow had a prescience that something was happening in the world against which his strength was of no avail-as if he knew the security of his high place was gone." She mused that the animal had "been indeed the King of the African forests," capable of crushing or 
strangling a lion or capturing an elephant." Unlike Akeley, Bradley indulged in flights of fancy, seeing the gorilla as it had been in the public mind - a beast capable of unfathomable violence (116-17). More noteworthy, not only did she anthropomorphize the ape, Bradley bolstered the image of the gorilla as the masculine progenitor, who knew he must step aside for man to assume his right/rite of having dominion over the animals. Such thoughts on the role of gorilla in the order of things did not follow the slaying of the female apes. It appears that the African forests were also a man's world.

During the day, the men worked on preserving the gorilla for the museum (Akeley, In Brightest Africa 231). Later that evening, in a moment of curiosity, the Wazungu (whites) of the safari party sought communion with the dead gorilla. In an exercise of quasi-cannibalism, for in their minds the gorilla was a long lost relative, or at best a cousin to the "savage" African, they cooked the meat and ate a little as a lark, finding it "firm and sweet." Mary Bradley noted that she "couldn't get over the family feeling of sampling grand-uncle Africanus" as they feasted in ritual over the body of their "primitive cousin" (Bradley 118, 121), the evolutionary father figure. It is worth noting that Bradley genders the ape as male. They did not "sample" the mother; as in the Freudian family romance, it is the body of the father/male figure that is cannibalized. Interestingly, the African porters refused to eat the meat. ${ }^{6}$ In her narrative, Bradley reveals that the racial assignments had been reversed. The stereotypical cannibalistic Africans-images of whom propped up the colonial project and legitimated Belgian empirebuilding in the Congo-expressed repulsion at the prospect of eating the ape, while the civilized whites appeared nonplussed.

As if taking in the enormity of eating "uncle" Africanus, members of the safari party contemplated their role in hunting gorillas. Reminiscent of the colonial/imperial enterprise, they justified their shooting of five gorillas for science as destruction in the name of improvement. As Europeans destroyed the Congo rainforests to ship rubber to the West to support industrializa- tion, similarly they killed apes to produce scientific knowledge about race. These were necessary evils. Yet Akeley rejoiced at seeing other gorillas disappear "none the worse for having met with white men." And, Mary Bradley proclaimed: "There is no reason for keeping the gorilla on the game lists." She argued that it was too "valuable" and "rare" to be hunted and killed. She called for the creation of gorilla preserves and official (e.g., colonial) protection of the gorilla, so that it would not "go the way that so many great beasts have gone- the way that all are going fast now in Africa." After estimating that Mts. Mikeno and Karisimbi might contain seventy-five to one hundred gorillas (In Brightest Africa 235), Akeley, like Bradley imagined a vanishing Africa (Akeley, In Brightest Africa 235; Bradley 132). The gorilla had become a symbol of a by-gone age in Africa; a tangible link to man's primordial past that only conservation could save. With a heavy heart and a full bag of specimens, the group departed for the White Friar's Mission (Akeley, In Brightest Africa 235).

\section{A Sanctuary for All Times}

The meditations of Akeley and the Bradleys while on safari underscored Akeley's campaign to lobby the Belgian Government to create a gorilla sanctuary in the Lake Kivu district. Upon returning to the United States, Akeley appointed himself the protector/savior of the vanishing gorilla. Through lectures and literary output, he cautioned a complacent America that the gorilla in Africa would go the way of the many species that once roamed North America. He attempted to mobilize as many followers as possible behind his mission by corresponding with noted scientists, intellectuals, and foreign dignitaries. More importantly, Akeley's politics of preservation reinforced imperialist rhetoric that presented the "Empire" as benevolent protector (Ranger 221-22).

Akeley's terminology used to describe the place where his simian friends would thrive reflects the importance he assigned to the project. In one of his earliest correspondences regarding 
the gorilla reserve, Akeley termed the area where the gorillas would be protected a "reservation."7 In conservation discourse, the British tended to use the term "preserve." Thus, Akeley's use of this word is crucial in that it reveals his American sensibilities. During his lifetime, a reservation (in terms of land) defined a place where the government placed Native Americans in an attempt to "protect" them from the onslaught of civilization. The reservation system rhetoric attempted to downplay the real politics behind its inception-to claim fertile and productive land from native peoples under eminent domain and visions of Manifest Destiny. However, some white advocates of the reservation system did indeed view it as the only vehicle with which the "dying" cultures of Native Americans could be preserved and where "tribes" could live in some autonomy away from the government. In paternalist rhetoric, white Americans construed Native Americans as an endangered species, much like the buffalo of the Great Plains (Berkhofer 166-74). Similarly, some Europeans in the early twentieth century argued for creating reserves for "endangered" tribes in Africa. Members of the Royal African Society and the Congo Reform Association advocated for the protection of the so-called Pygmies as deforestation in the rubber regions of the Congo River Basin and other imperial projects threatened to undermine their lifestyles. ${ }^{8}$ In calling the gorilla preserve a reservation, Akeley made the Indian tribe and the gorilla band interchangeable. His implications were clear. On a reservation, the "primitive," be it man or animal, would be protected from and by the white man.

Akeley considered the reservation a sacred place, as he romanticized the refuge as the gorillas' "sanctuary for all times." The reservation would be a place of worship, where a biological research station would attract would-be congregants. The gorilla would be safe from white hunters. However, Akeley realized that such a place could not exist unless the colonial government of the region saw the imperative for protecting the gorilla. For millennia the gorilla endured and now it faced extinction, according to Akeley. Ironically, he sought cooperation from the same government that issued thousands of hunting licenses to Europeans and Americans to hunt the gorilla and thus, helped facilitate the "disappearance" of the gorilla in less than a century. ${ }^{\text {? }}$

The Belgian government sympathized with Akeley's plan, for as early as 1901, it had issued a decree to regulate hunting in its African territories. King Leopold II began to envision the creation of a national park based upon the model of Yellowstone National Park. However, it was after the death of the king and the transfer of ownership of the Congo to the Belgian State that Prince Albert (after traveling to the Congo in 1909) recognized the necessity for creating reserves to protect flora and fauna. Unfortunately, the Great War prevented the prince from realizing his dream. After a trip to the United States in 1919, to visit American national parks, King Albert revived Leopold's plan to create a wildlife refuge in the Congo (Parc National Albert 10, 12, 14). Thus, Akeley's desire to protect the gorillas of Kivu corresponded with a long-held desire of the Belgian royalsa desire that cast the regents (alive and postmortem) as benevolent imperialists in the eyes of the Western world. ${ }^{10}$

After securing additional support from scientists, scientific institutions, and government plenipotentiaries - the AMNH, Robert Means Yerkes (a psychologist at Yale University and affiliate of the National Research Council in Washington, DC), the National Geographic Society, Baron de Cartier de Marchienne (Belgian Ambassador to the United States), and James Gustavus Whiteley (Consul of Belgium) - Akeley still faced obstacles. The gorilla sanctuary was not a foregone conclusion. Setting aside valuable land in a colonial territory would require support from the Belgian elite and business community. Whiteley sent copies of Akeley's articles on the gorilla to government officials and "personal friends." These men had to be convinced that it would be in the best interest of the empire to save the gorilla. As a result, Akeley's narratives of the gorilla expedition began to appear in more print media, including The World's Work, which claimed a wide readership in America and Europe. Eventually, his gorilla tales would be published in his book, In Brightest Africa. Reve- 
lations of slaughtering safaris (of course not conducted by Akeley) and dire predictions of the disappearance of teeming bands of gorillas culminated in images of vulnerable, docile, family-oriented primates preyed upon by man. The haunting image of seeing man's distant relative (one key to the missing link) obliterated by civilization validated the expensive undertaking to create a gorilla preserve. ${ }^{11}$

The frenzy to obtain a firm commitment to the gorilla sanctuary (as it was being called in late 1922) left a bitter taste in the mouths of many hunters and governments. Akeley's descriptions of indiscriminate killings of gorillas were met with acrimony and suspicion. In order for Akeley to advance his cause he had to furnish indisputable proof that the numbers of gorillas in the Kivu district were rapidly depleting and that greedy white hunters were at fault. In his plea for the primates, Akeley casually noted: "If being molested by man would make gorillas ferocious and aggressive, these animals should have been excessively dangerous, for within a very short time the Prince of Sweden had shot fourteen of them, and Barns had killed several more. The very animals that I followed had probably heard the guns of these other men" (In Brightest Africa 216). Noted popular magazines and science journals quoted Akeley's statements in articles, as well as his estimation that fifty to a hundred gorillas were left in the region. These publications elicited harsh retorts.

For example, the Swedish charged Akeley with being a hypocrite for criticizing the Swedes collecting of fourteen specimens and Barns' shooting of "several more," when he himself had shot five gorillas. Wils Glydenstople of the Royal Natural History Museum in Stockholm went to great pains to list the specimens collected and their subsequent use in the museum, as well as the Swedes' securing of the requisite rites and permissions to hunt in the Congo. He disparaged Akeley's statements as "inaccurate" and motivated by jealousy. Interestingly, never in the letter did Glydenstople dismiss the need for a reserve; rather, he refuted the claim that the Prince was part of the slaughtering safaris endangering African wildlife. ${ }^{12}$
As the Belgian government's decision to create a gorilla preserve gained international coverage, other nations seized on the opportunity to promote preservation of rare African fauna. The (London) Times published an article on the disappearance of the rare game in Africa, and praised the British government and societies (like the Society for the Preservation of Fauna of the Empire) for furthering the movement for game preservation. The paper also credited the British for initiating the movement to protect the gorilla. Upon reading the article, Akeley requested that Whiteley write a letter to the Times "so that the Englishmen will have the facts and not run away with the idea that they have done the whole trick." Akeley pledged to arm Whiteley with "a lot of facts" for him to include in the letter. ${ }^{13}$ This matter was crucial as the Belgian government had yet to state exactly what actions they would take on behalf of the gorilla sanctuary. ${ }^{14}$ Nevertheless, in a letter to editor of the Times, Whiteley picturized the "sanctuary" that would be "a sort of Garden of Eden where animals [would] live in peace, amid their natural surroundings, without fear of man." More importantly, he confirmed that the idea for the sanctuary was "first suggested" by Akeley and that the plans for the preserve would be carried out in accordance with Akeley's wishes. ${ }^{15}$

By 1925, the Belgians had issued the Royal Decree to establish the park. It named the preserve "Parc National Albert" (a.k.a. Albert National Park), which comprised the mountains Mikeno, Karisimbi, and Vissoke. In the zone, the colonial government outlawed the "killing, capture or pursuit," and hunting of the gorillas, as well as that of any other wild animal, unless the latter was killed in "legitimate self-defense." The park would be guarded by a combination of a conservation corps and a corps of "special native police." Insightfully, Akeley had argued early on that the protection of the park required the cooperation of the Africans, which could "be obtained through giving careful thought and considerations to their needs and rights."16 Akeley observed: "[T] he natives of this region have disturbed the gorillas very little, nor have the gorillas disturbed the natives. Certain it 
is that the gorillas got along very well till the white men came along with guns." 17

Although the creation of the first official gorilla sanctuary was a success, some scientists felt that the decree to create the park "proved to be insufficient for allowing for the perfect scientific development of the institution" that would be dedicated to studying and protecting the gorilla. Thus, Akeley and Belgian J. M. Derscheid, naturalist and professor of science at L'Université Coloniale D'Anvers would conduct a reconnaissance of the volcanoes within the park and study the life and customs of the Kivu gorillas. In 1925, the party set out for Africa, this time with a team of landscape artists and "preparators" (taxidermists). Armed with funding from film magnate George Eastman, AMNH trustee Daniel E. Pomeroy, and Colonel Daniel B. Wentz of Philadelphia, Akeley planned to devote six weeks to studying the Mikeno, Karisimbi, and Vissoke region and to film gorillas on the top of Mt. Karisimbi. Unfortunately, his trip to Kivu would be his last African adventure. Akeley died from complications of a fever suffered in Kivu, where his wife and colleagues subsequently buried him (Parc National Albert 18; Derscheid 15, 23-24; President's Annual Report 14; M. Akeley 1, 3, 5; Leigh 31, 48, 65-93).

Akeley's death did not bring a halt to the museum's systematic study of the gorillas. Although Mary Jobe Akeley assumed leadership of the expedition, her findings were not the last word on African primates. In 1929, the AMNH partnered with Columbia University to sponsor an expedition to examine gorilla behavior and bring back specimens of gorillas for anatomical study. This expedition was to be wider in scope, encompassing the Kivu region (Parc National Albert) and the forests of Cameroon to the east (Rexer and Klein 126-27). The search for the key to the origins of man would continue.

The gorillas immortalized in narrative and subsequently presented in the AMNH Akeley African Hall, were part of a band from which they had been torn. They were "black" mothers, fathers, and babies, rarely termed "gorillas" in Akeley's text, as if to emphasize their proxim- ity to "blacks" on the evolutionary scale. In diorama they presented a fictionalized image of the peaceful human family, obscuring the brutality and randomness associated with the securing of them as specimens. In reading the diorama, it seems as if the safari party came across a family, a father, mother, perhaps a daughter (the identities of the two females are indistinguishable), and a child at play-despite the fact that the safari party observed the gorillas traveling in bands with one or two males and disproportionately more females. Mary Bradley wrote:

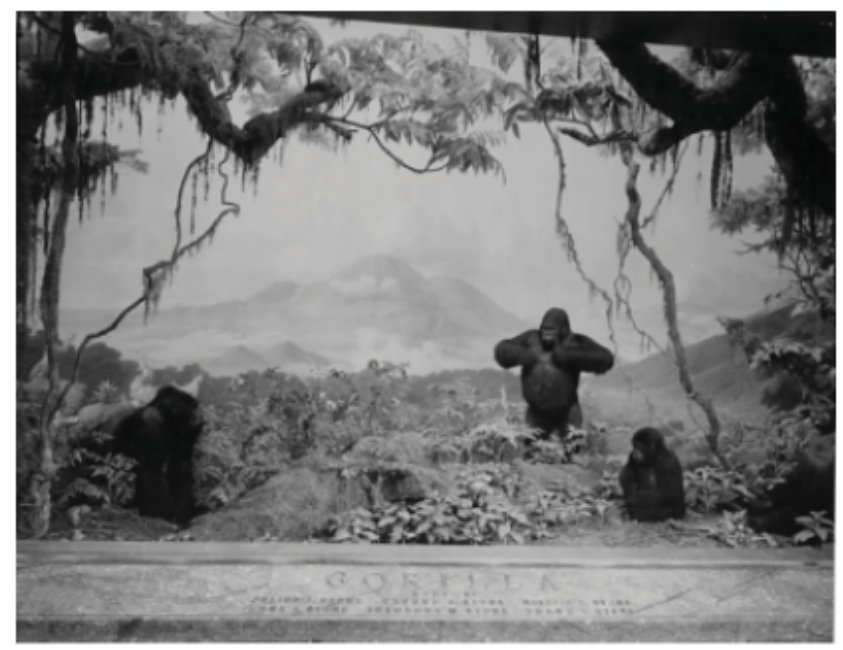

The question arises whether those bands consisted of two or more respectable monogamous couples and their marriageable daughters-maiden gorilla yet unculled by roving gallants-or whether it consisted of a couple of gorilla gentlemen and their respective harems or of unassorted [sic] and liberally inclined ladies and gentlemen ... We can only offer the situation, not the solution. (133)

The analogies to "exotic" human sexual relationships and virginity were explicit. References to harems and polygamy juxtaposed marriages among "savages" to monogamous, "civilized" people. Yet Bradley left some room for the reader to equate gorilla mating with the "bohemian" sexuality of the 1920s that embraced the primitive, or with anthropological treatises on "savage sexuality." Indeed, Bradley's fascination with the sex lives of 
apes and her anthropomorphizing of them could be seen as a natural history precursor to anthropologist Bronislaw Malinowski's 1929 book The Sexual Life of Savages (Torgovnick 112). Bradley's commentary on the gorilla's sex life (or possibility of it) allowed her an opportunity to discuss subjects otherwise unsuitable for a respectable American woman and to step outside of constructed white femininity. It was clear that Akeley wanted to present the gorillas in diorama as a monogamous nuclear family. In showcasing the gorillas qua respectable family, Akeley distanced them from associations with "uncivilized" sexual practices discussed in Bradley's narrative. Akeley's gorilla family soothed the white, middle-class museum patrons' sensibilities and entreated them to join in the fight to protect the gorilla.

Akeley contended that humans had a responsibility to apes, which were immature humans, that is, precursors to humanity proper. For Akeley, the gorilla was father. Thus, the killing of the ape was actually an usurpation of patriarchy-the murder of the progenitor so that the man-child could emerge as leader of the clan/tribe. Using evolutionary theory, the primitive (gorilla) had to be conquered in order for the civilized (man) to take his place in the order of things. Read in this light, the campaign for the sanctuary was actually a form of survivor's guilt. The gorilla preserve was created out of a sense of culpability in the lamentable, yet necessary death of the evolutionary father. This is not Victor Frankenstein chasing after his creation-the monster-until he himself dies, but rather the eldest male killing his father to assume power. After all, Akeley's death occurs on the second trip in search of the gorilla, after the sanctuary had already been created, and not on the first trip during which Akeley had his "epiphany."

Mary Bradley's recollection of the gorilla hunt was equally Freudian, as she painted images of cannibalism and recounted rape fantasies to explain her fascination with the gorilla. Bradley imagined willingly absconding with the evolutionary father, even as she encouraged her metaphorical brothers to kill him for the greater good of the family (read science). Similarly, Bradley explained the eating of the slain gorilla's flesh in Freudian fashion - as a rite of initiation-evoking theories that cannibals ate the flesh of the deceased father in recognition of his patriarchal power, hoping to transfer that authority to themselves through the consumption of his body.

Both Akeley and Bradley's narratives of the hunt, however steeped in Freudian symbolism, were at odds with one another. This is a point that Haraway does not address, perhaps because her treatment of Akeley's gorilla quest focuses on his narrative. Moreover, Haraway offers us a snapshot into 1920s culture and fails to root Akeley's pursuit of the ape in a broader historical contextone that directly engages nineteenth century discourses on race and gender and their impact on early twentieth-century theories of evolution. Bradley, unlike Akeley, was not interested in redeeming apes from popular literary and cultural assumptions about their behavior. The selling of the gorilla as the tangible remnant of humanity and Africa's prehistoric past did not occur without tension or casualties. She advocated saving the gorilla regardless if theories of ape-human mating proved untrue. As the narratives of Bradley and Akeley clearly unveil, there was no defining consensus on gorilla behavior. Both anthropomorphized the gorilla to their own literary, scientific, and political ends.

\section{Cinematic Simians}

Akeley and Bradley's "primate visions" persisted in American culture and popular memory well into the late twentieth century-in film. Two years after Akeley's death on Mt. Karisimbi, the film The Missing Link appeared in theaters. It tells the tale of a white hunter, Lord Dryden, who goes to Africa accompanied by his friend, Colonel Braden, in search of the "missing link": the rumored half-man, half-ape who connects humanity to the great primates of Africa. In this farce, the men believe a pet chimpanzee is the missing link, until the hero-a young poet, who they hired as a baggage carrier-subdues the "real" missing link. The film, on its surface, is rel- 
atively benign and meant to elicit laughter from the audience. However, not all films featuring Africans and apes were so lighthearted. The film Ingagi released in 1930 billed itself as a "documentary." This motion picture featured apes "raping" black women, although there is a veiled understanding that black women somehow lured these lecherous animals. Since Western culture constructed the sexuality of these women as innately animalistic, it excused apes for feeling sexually drawn to them. With the release of King Kong three years later, a "mad" gorilla menaced white womanhood. Often read as a metaphorical tale of black men defiling white women, King Kong played on existing stereotypes of the hypersexual ape, and more radically the hypersexual desire of black men for white women. However, the latter cinematic commentary on gorilla (and black men's) sexuality made one thing patently clearthe white woman did not welcome the primate's (black man's) advances (Comaroff and Comaroff 98; Munden; Cameron 98, 217, 222). ${ }^{18}$ The apewoman trilogy, Wild Captive Woman (1943), Jungle Woman (1944), and Jungle Captive (1944) revealed that the white man did not seek the ape-woman (black woman's) embrace. Despite the efforts of Akeley and similarly minded naturalists, gorillas continued to be associated with aberrant sexuality and violence in the American imagination. Mary Bradley's simian lover lived on in the American psyche.

However, Akeley's vision of the gorilla triumphed in the end. Primatologist Dian Fossey's defiant cry: "Get off my mountain!" as dramatized by Hollywood actress Sigourney Weaver in Gorillas in the Mist (1988) signified a celluloid obfuscation of the history that brought Fossey and those African men to that mountain in 1967namely, the politics and legacies of imperialism. A white American woman had the "courage" to tell African "poachers" that she had taken ownership of the Virunga Mountains, in Rwan$\mathrm{da}$, and was protector to its resident gorillas in threat of extinction from them. In claiming those mountains as her space, Fossey evoked decades of white notions of privilege in the "Dark Continent." In her own attempt to protect the gorillas she had physically and metaphorically colonized Africa. That now famous encounter disclosed the imperial politics that facilitated the creation of gorilla sanctuaries in Africa and that consigned Africans to "poaching" to survive in the colonial economy. Fossey's dictum to Africans to leave the mountain broke with Akeley's call for cooperation between the colonial government and Africans-but, jolted a Western collective memory of white Americans (both fictional and real) braving the Dark Continent to save Africa from itself and for posterity.

One year after Fossey's arrival in Africa, Planet of the Apes (1968) appeared in theatres, reflecting both Akeley's simian fantasy and worst nightmare-gorillas (apes) flourished on Earth, unfortunately they have taken on all the mythological characteristics that linked them to stereotypes of Africans and "Negroes." The apes are ferocious, avaricious, and greedy humanoids — missing links on a rampage. Worst yet, they hate humans, whom they have enslaved. Interpreted by scholar Eric Greene as an allegorical tale of race relations in the 1960s, the simian world of Planet of the Apes engages the same questions that plagued the early twentieth century, marked by race riots and lynchings. Can the apes ("Negroes") and whites live together in harmony? Like Akeley in his gorilla narratives, the screenplay writer mapped onto the film all the social, cultural, and political concerns of the era.

The simian dystopia gave way to more benign primate visions by the 1980s and 1990s. The release of Disney's Tarzan (1999) featuring a revamped Tarzan (a dred-locked and tree-swinging wonder) and Jane as impassioned primatologist (a cross between Fossey and Jane Goodall), resuscitated a racist novel (Edgar Rice Burroughs' Tarzan of the Apes) to promote compassion for the gorillas. Conspicuously absent of Africans (a la The Lion King fantasy), Tarzan presents Africa as a primordial wonderland facing destruction from avaricious Great White Hunters. However, Tarzan is no Akeley. Kerchak's death scene parallels that of "grand-uncle Africanus" in one important way-both left the white man "king" of the African jungle. 


\section{Notes}

1. Carl Akeley to Henry Fairfield Osborn, January 18, 1921, A.A31, Box 7 Number 42, AMNH, University of Rochester Libraries/ Department of Rare Books and Special Collections (Hereafter URL/DRBSC), Rochester, New York.

2. Ibid.

3. Mary's daughter Alice Hastings Bradley Sheldon went on to become the famed science fiction writer James Tiptree Jr. Fittingly, her works explore themes of biological determinism, sexuality, science, and man's determination to destroy the planet. See Judith Genova (7-9).

4. See Andre Battel, Ernest George Ravenstein, Samuel Purchas, and Anthony Knivet, The Strange Adventures of Andrew Battel of Leigh, in Angola and the Adjoining Regions (London: the Hakluyt Society, 1901).

5. Carl Akeley to George H. Sherwood, February 28, 1921; A.A31, Box 7 Number 42, AMNH, URL/DRBSC.

6. As many porters were Muslims, it is possible that they refused to eat the meat because it was forbidden under the strictures of Islam.

7. Carl Akeley, to Robert Yerkes, April 31, 1922, A.A31, B7/F29, CEAP, URL/DRBSC.

8. For more on advocates for creating preserves for endangered tribes see P. H. G. Powell-Cotton, "Notes on a Journey Through the Great Ituri Forest," Journal of the Royal African Society 7.25 (Oct. 1907): 1-12; N. W. Thomas, "Sir Harry Johnston on 'George Greenfell and the Congo," Journal of the Royal African Society 8.21 (Oct. 1908): 21-30; and Phillipe Verner Bradford and Harvey Blume, Ota Benga: The Pygmy in the Zoo (New York: Dell Publishing, A Division of Bantam Doubleday Dell Publishing Group Inc., 1992).

9. Akeley to Yerkes.

10. The decision to create what would become a national park in the Belgian Congo did not begin with Akeley. In 1888, English explorer Major von Wissmann promoted the creation of a game reserve in equatorial Africa. At the turn of the century, the International Conference for the Protection of Wild African Animals was held in London, where Wissmann's idea was taken up.

11. Wils Glydenstople to Captain A. Gyde, September 14, 1923, MLJAC (MSS.A342), Box 3 Folder 11.

12. Glydenstople to Gyde.

13. Carl Akeley to James Whiteley, July 1, 1924, MLJAC (MSS. A342), Box 3 Folder 12.

14. James Whiteley to Carl Akeley, New York, July 29, 1924, MLJAC (MSS.A342), Box 3 Folder 12.

15. Draft of James Whiteley, "A Gorilla Sanctuary," The (London) Times, September 5, 1924, in MLJAC (MSS.A342), Box 3 Folder 12.

16. Albert, King of the Belgians, To all present and to come.

17. Akeley quoted in Albert, King of the Belgians, To all present and to come, March 2, 1925, (Copy of translation), Mary L. Jobe Akeley Correspondence (Hereafter MLJAC) (MSS.A342), Box 3 Folder 13, CEA: Correspondence, Gorilla Sanctuary; AMNH Archives, New York.

18. According to Cameron, copies of Ingagi did not survive. Perhaps its offensive nature led the distributor to pull the film and destroy all existing copies of the movie.

\section{Works Cited}

Akeley, Carl E. "Gorillas—Real and Mythical." Natural History 23.5 (1923): 429-36.

Akeley, Carl E.. In Brightest Africa. New York: Doubleday, 1924.

Akeley, Mary Jobe. Carl Akeley's Africa: The Account of the AkeleyEastman-Pomeroy African Hall Expedition of the American Museum of Natural History. New York: Blue Ribbon, 1929.

Barns, T. Alexander. "Ngorongoro, the Giant Crater; And the Gorilla, the Giant Ape (Continued)." Journal of the Royal African Society 22.88 (1923): 278.

Berkhofer, Robert F. Jr. The White Man's Indian: Images of the American Indian from Columbus to the Present. New York: Vintage, 1978.

Bourdieu, Pierre. Outline of a Theory Practice 1977. Cambridge: Cambridge UP, 2004.

Bradley, Mary Hastings. On The Gorilla Trail. New York: D. Appleton-Century, 1936.

Bulmer, Michael. Francis Galton: Pioneer of Heredity and Biometry. Baltimore: The John Hopkins UP, 2003.

Cameron, Kenneth M. Africa on Film: Beyond Black and White. New York: Continuum, 1994.

Collins, Patricia Hill. Fighting Words: Black Women \& The Search for Justice. Minneapolis: U of Minnesota P, 1998.

Comaroff, John, and Jean Comaroff. Of Revelation and Revolution: Christianity, Colonialism, and Consciousness in South Africa. Chicago: U of Chicago P, 1991.

Derscheid, J. M. La Protection Scientifique de la Nature. Brussels: 1927.

Desmond, Adrian. The Politics of Evolution: Morphology, Medicine, and Reform in Radical London. Chicago: U of Chicago P, 1989.

Genova, Judith. "Tiptree and Haraway: The Reinvention of $\mathrm{Na}$ ture." Cultural Critique 27 (1994): 5-27.

Gilman, Sander. "Black Bodies, White Bodies: Toward an Iconography of Female Sexuality in Late Nineteenth-Century Art, Medicine, and Literature." "Race," Writing, and Difference. Ed. Henry Louis Gates, Jr. Chicago: U of Chicago P, 1985. 223-61.•

Gorillas in the Mist. Dir. Michael Apted. Perf. Sigourney Weaver. 1988. DVD. California: Universal Pictures, 2004.

Greene, Eric. Planet of the Apes as American Myth: Race, Politics, and Popular Culture. Hanover, NH: Wesleyan UP, 1998.

Haraway, Donna. Primate Visions: Gender, Race, and Nature in the World of Modern Science. New York: Routledge, 1989.

Iliffe, John. Africans: The History of a Continent. Cambridge: Cambridge UP, 1995.

Jungle Captive. Dir. Harold Young. Perf. Vicky Lane. 1944. Universal Home Video, 1998.

Jungle Woman. Dir. Reginald Le Borg. Perf. Acquanetta. 1944. Universal Home Video, 1998.

Kohlstedt, Sally Gregory. "Henry A. Ward: The Merchant Naturalist and American Museum Development." Journal of the Society for the Bibliography of Natural History 9.4 (1980): 647-56.

Leigh, William Robinson. Frontiers of Enchantment: An Artist's Adventures in Africa. New York: Simon and Schuster, 1938.

“The Missing Link.” Ward's Natural Science Bulletin June 1881: 8.

Munden, Kenneth W. The American Film Institute Catalog of Motion Pictures Produced in the United States: Featured Films, 1921-1930. New York: R. R. Bowker, 1971. 
Parc National Albert = Nationaal Park Albert. Brussels: 1934.

Planet of the Apes. Dir. Franklin Schaffner. Perf. Charlton Heston and Roddy McDowall. 1968. DVD. California: Fox. 2004.

President's Annual Report. New York: American Museum of Natural History, 1925.

Ranger, Terence. "Whose Heritage? The Case of Matobo National Park." Journal of Southern African Studies 15.2 (1989): 217-49.

Rexer, Lyle, and Rachel Klein. American Museum of Natural History: 125 Years of Expedition and Discovery. New York: H. N. Abrams, 1995.

Schiebinger, Londa. Nature's Body: Gender and the Making of Modern Science. Boston: Beacon, 1993.

Stoler, Ann Laura. Race and the Education of Desire: Foucault's History of Sexuality and the Colonial Order of Things. Durham: Duke UP, 1995.

Stoler, Ann Laura.. Carnal Knowledge and Imperial Power; Race and the Intimate in Colonial Rule. Berkeley: U of California P, 2002.
Tarzan. Dir. Chris Buck and Kevin Lima. Perf. Tony Goldwyn, Minnie Driver, Glenn Close, Brian Blessed, and Nigel Hawthorne. 1999. DVD. Disney, 2000.

Todorov, Tzvetan. The Morals of History. Trans. Alyson Waters. Minneapolis: U of Minnesota P, 1995.

Torgovnick, Mariana. Gone Primitive: Savage Intellects, Modern Lives. Chicago: U of Chicago P, 1990.

"To the Gorilla in the Rochester University." Ward's Natural Science Bulletin April 1882: 9.

Warren, Adrian. "Mountain Gorillas.” Accessed on 17 May 2005 http://www/lastrefuge.co.uk/data/articles/gorillas_p2_2.html

Wild Captive Woman. Dir. Edward Dmytrk. Perf. Acquanetta, John Carradine, and Milburn Stone. 1943. VHS. MCA Home Video, 1994. 